\title{
E-GOVERNMENT SERVICES IN MOLDOVA: VALUE AND OPPORTUNITIES
}

\author{
Mihai Grecu ${ }^{1}$, Ilie Costaș ${ }^{2}$ and Artur Reaboi ${ }^{3}$
}

\begin{abstract}
Technological progress in ICT has created conditions for a new government paradigm - from a government that leads to a government providing services to society. Technology changes the nature of the connection between government and citizens: governance becomes more participatory and citizens' interests prevail.
\end{abstract}

The impact of e-Government solutions is complex, on multiple levels, depending on the maturity of the models applied and the capacity of citizens and business to assimilate e-Government services. In a short time, electronic government services in Moldova have evolved from simple information services to integrated transactional services.

On the one hand, this is due to high performance telecommunications infrastructure (broadband, $2 G, 3 G$ and $4 G$ technology) and, on the other hand, to citizens' expectations that boosted recently and determined the government to accelerate the implementation of new e-services, increasingly complex and a better quality.

The paper addresses the issue of e-Government services in terms of the value that it gives to the government and to citizens' lives and analyzes opportunities to develop e-Government services in the new technological and social realities.

\section{Introduction}

The achievements in the information technology and communications have significantly changed the communication process between the government, citizens and business. This has created opportunities for developing new types of relationships in the governance process that have positively impacted the efficiency and effectiveness of the governance act.

The wide access to Internet changed the way government provides services to citizens. Today governments are making efforts to accelerate the development of more complex e-Government services not only to ensure better quality services but also to improve the efficiency and effectiveness of the government and render its activities more transparent [7].

The aim of the electronic services is to provide faster public services of better quality and with an as low as possible administrative burden. Effectiveness of government providing the service must increase with the development of electronic services. [12].

\footnotetext{
${ }^{1}$ Information Society Development Institute, Academiei str., 5A, Chișinău, Moldova.

${ }^{2}$ Academy of Economic Studies, Bănulescu-Bodoni str., 59, Chișinău, Moldova.

${ }^{3}$ e-Government Center, Piata Marii Adunari Nationale 1, Chisinau, Moldova.
} 
The interest in e-Government in Moldova has significantly increased along with the creation of the Centre for e-Government in May 2010 and the adoption of an ambitious strategic program of technological modernization of governance (e-Transformation) in 2011 [13].

The program has set the following objectives:

- Implementation of transparent, efficient and responsive governance;

- Modernization of the public services through digitization and re-engineering processes;

- $\quad$ Improvement of governance by ensuring the interoperability of IT systems, consolidation and reuse of resources.

Achieving these goals requires a comprehensive and deeper approach to the re-technologisation of governance, streamlined business processes that ensure government activities and the implementation of new models of public services.

This study aims at examining the most important achievements in electronic services that occurred in Moldova in the recent years, analyzing the impact these services have on people's life and work, as well as at identifying opportunities for the further development of e-Government.

\section{2. e-Government in Moldova - initiatives and achievements}

The implementation of electronic services is possible if there are sufficient premises [2]. In Moldova there are sufficient of such premises. Moldova has a well-developed network of electronic communications. Fixed telephony provides broadband rate of $14.7 \%$, while mobile $-49.4 \%$. Fixed telephony has a penetration rate of $35.2 \%$, while the penetration rate of the mobile telephony is $108 \%$. Fixed broadband Internet is used by $14.7 \%$ of the population, whereas $46.6 \%$ use mobile broadband internet.

$\begin{array}{llrlrrrl}\text { Rank } & \text { Country } & \text { EGDI } & \begin{array}{r}\text { EGDI } \\ \text { Level }\end{array} & \text { OSI } & \text { TII } & \text { HCI } & \text { Level of Income } \\ 35 & \text { Russian Fed. } & 0,7215 & \text { High } & 0,7319 & 0,6091 & 0,8234 & \text { High Income } \\ 36 & \text { Poland } & 0,7211 & \text { High } & 0,7029 & 0,5857 & 0,8747 & \text { High Income } \\ 46 & \text { Hungary } & 0,6745 & & 0,6304 & 0,5615 & 0,8317 & \text { Upper Middle Income } \\ 49 & \text { Belarus } & 0,6625 & & 0,4855 & 0,6304 & 0,8716 & \text { Upper Middle Income } \\ 50 & \text { Czech Republic } & 0,6454 & & 0,4783 & 0,5952 & 0,8627 & \text { High Income } \\ 52 & \text { Bulgaria } & 0,6376 & & 0,5652 & 0,5602 & 0,7875 & \text { Upper Middle Income } \\ 62 & \text { Ukraine } & 0,6076 & & 0,5870 & 0,3968 & 0,8390 & \text { Lower Middle Income } \\ \mathbf{6 5} & \text { Moldova } & \mathbf{0 , 5 9 9 4} & \text { High } & \mathbf{0 , 5 9 4 2} & \mathbf{0 , 4 8 5 0} & \mathbf{0 , 7 1 9 1} & \text { Lower Middle Income } \\ 67 & \text { Slovakia } & 0,5915 & & 0,4420 & 0,5504 & 0,7822 & \text { High Income } \\ 75 & \text { Romania } & 0,5611 & & 0,4565 & 0,4533 & 0,7736 & \text { Upper Middle Income } \\ & \text { Eastern Europe } & 0,6422 & & 0,5674 & 0,5428 & 0,8166 & \\ & \text { Europe } & 0,7241 & & 0,6926 & 0,6438 & 0,6897 & \end{array}$

Table 1: E-Government Development Index in Eastern Europe countries, 2016 [15] 
Moldova has a high level of e-Government Development Index, with ratios between 0.50 and 0.75 (Table 1). Also, it is one of the few countries with lower middle income that made it to the top 50 countries, of which 26 are European countries that have the largest e-participation index (0.6610), with high levels of OSI - between 0.50 and 0.75 (Figure 1).

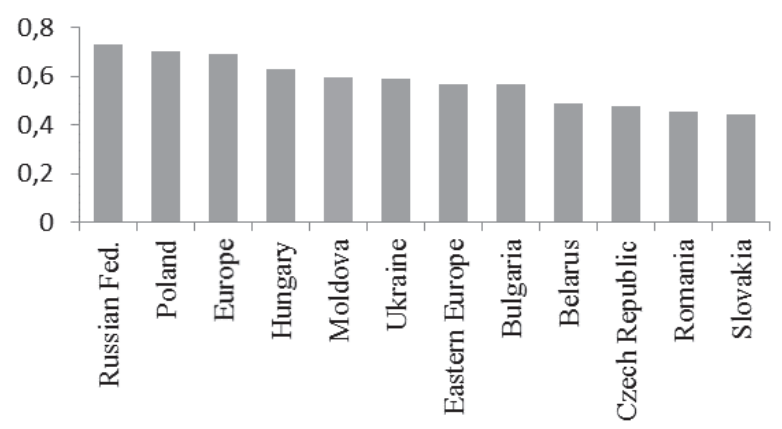

Figure 1: Online Service Index in Eastern Europe

E-Government Development Index - EGDI (UN surveys) is growing on the Online Service component - OSI, and Telecomm Infrastructure component - TII. Component Human Capital HCI has not progressed during recent years and even declined (Figure 2) [14], [15].

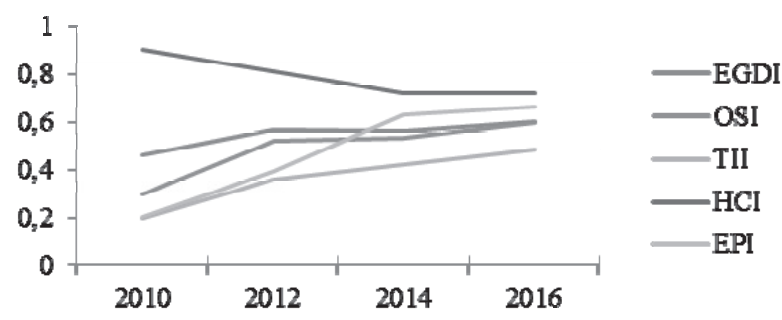

Figure 2: E-Government Development Indexes in Moldova

The successful implementation of public electronic services depends greatly on citizens' perception of how public services are provided. The usefulness, ease and ability to use electronic services and people's trust in open and responsible governance are important conditions for the adoption and development of the e-Government [10], [11], [12].

As the program of technological modernization of the government [13] was launched, consultations on the implementation of e-Services initiatives were conducted with relevant social actors, public officials, business representatives and civil society. Next on, the consultations focused on the delimitation of more required services, taking into account citizens' priorities and conditions of feasibility and sustainability of new services.

As at December 2016, 567 services were registered on the portal of public services, servicii.gov.md, of which 126 were being provided electronically. Among the most popular services are: 
- Issuance of criminal record,

- Access to data from real estate register,

- $\quad$ Licensing of road transport,

- Checking personal data,

- Checking data on legal entities,

- ID card issuance,

- Issuance of birth certificate,

- Passport issuance,

- Issuance of information from the state archive,

- $\quad$ Licensing of construction activities.

Surveys on the perception of e-Government and electronic public services (http://www.egov.md/ro/resources/polls) show a significant increase in citizens' interest in the electronic governance model (Figure 3).

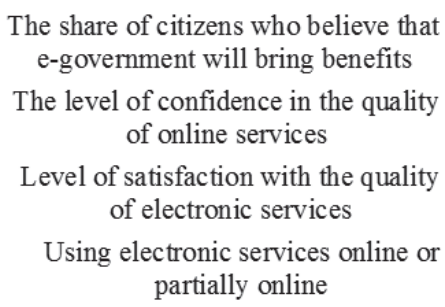

Figure 3: Accessing public services online or partially online

The number of citizens using electronic services increased, and the satisfaction level of individuals and businesses benefitting from such services increased as well, as they had a positive impact on the quality of their life and work. This is due to the fact that people use increasingly more computers and mobile devices, which leads to a higher degree of connection to Internet (Figure 4).

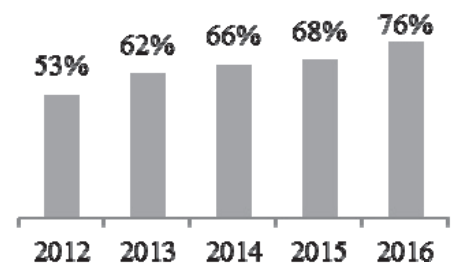

Figure 4: Level of connection of households to the Internet 
The social impact is different for different categories of citizens. It depends on age, education level, income level, place of residence, urban-rural, etc. It is certain, however, that the impact is positive, with a clear upward trend. The growing number of users of e-services, and the desire and willingness to adopt and use new services are eloquent proofs of this.

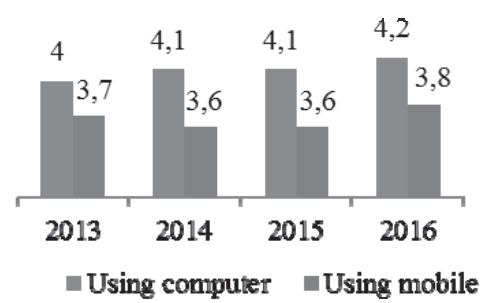

Figure 5: Willingness to use online services (1 - unwilling, 6 - want very much)

\begin{tabular}{|c|c|c|}
\hline Service & Release Date & Indicators in December 2016 \\
\hline Open Data Platform (date.gov.md) & April 2011 & $\begin{array}{l}937 \text { datasets, } 48 \text { public authorities, } 241425 \\
\text { unique visitors, } 334178 \text { visits per portal, } 2 \\
333685 \text { sets of data downloaded. }\end{array}$ \\
\hline Portal servicii.gov.md & May 2012 & $\begin{array}{l}566 \text { information services, } 125 \text { interactive } \\
\text { services, } 556 \text { services available, } 658231 \\
\text { unique visitors, } 1070262 \text { visits per portal. }\end{array}$ \\
\hline Registry of personal data operators & August 2012 & $\begin{array}{l}877 \text { registered public institutions, } \\
1808 \text { public information systems }\end{array}$ \\
\hline e-Application for criminal record & September 2012 & $\begin{array}{l}607842 \text { requests, } 97.47 \% \text { opted for the } \\
\text { solution online, } \\
\text { The rate of uptake of the service has reached } \\
99,15 \% \text { in } 2016 \text {. }\end{array}$ \\
\hline Mobile digital signature & September 2012 & $\begin{array}{l}89465 \text { users of mobile digital signature, } \\
2662577 \text { transactions. }\end{array}$ \\
\hline e-Application for business license & November 2012 & $\begin{array}{l}25078 \text { requests for license, } \\
79.31 \% \text { requests online, } \\
\text { The share of online applications has reached } \\
100 \% \text { in } 2016 \text {. }\end{array}$ \\
\hline e-Normative documents in construction & January 2013 & 129486 downloads data. \\
\hline $\begin{array}{l}\text { e-Reporting to the National Social Insurance } \\
\text { House }\end{array}$ & February 2013 & $\begin{array}{l}746907(96.27 \%) \text { online reports, } 61.50 \% \text { - } \\
\text { digitally signed. }\end{array}$ \\
\hline $\begin{array}{llll}\text { e-Reports for National Health Insurance } \\
\text { Company }\end{array}$ & July 2013 & 42602 reports, 152669 people registered. \\
\hline $\begin{array}{l}\text { Mpay - government electronic payment } \\
\text { service }\end{array}$ & September 2013 & $\begin{array}{l}3471039 \text { transaction, } \\
\text { More than } 50 \text { services connected to Mpay, } \\
33 \text { public authorities and operators of } \\
\text { payments connected to Mpay. }\end{array}$ \\
\hline e-Invoice & February 2014 & $\begin{array}{l}4454 \text { businesses connected to e-invoice, } \\
2697067 \text { invoices generated. }\end{array}$ \\
\hline e-Civil Status & December 2013 & $\begin{array}{l}11988 \text { certificates issued, } \\
2266(19.0 \%) \text { of which are required online. }\end{array}$ \\
\hline Mcloud - Government Cloud & February 2013 & $\begin{array}{l}38 \text { government agencies have migrated their } \\
\text { systems to Mcloud }\end{array}$ \\
\hline $\begin{array}{l}\text { Mpass - authentication for governmental } \\
\text { electronic services }\end{array}$ & December 2014 & 39 information systems integrated \\
\hline
\end{tabular}


Citizens who frequently interact with the government are usually employees who have a higher education degree, higher income, and use computers and the Internet more frequently. These people are also more receptive to electronic services (Figure 5).

Performance indicators of the most relevant electronic public services are shown in Table 2. We have to mention that some services reached a rate of almost total assimilation, particularly transactionrelated services.

The mobile signature is one of the successful solutions, which is the result of a public-private partnership. Mobile signatures provided by mobile operators are used by the tax inspectorate services, civil service, health insurance services, social insurance, licensing services, services of the Ministry of Justice and others.

Public sector computerization initiatives raised the issue for researchers to identify factors influencing the adoption of the e-Government. According to [10] these factors include: service benefits, management, costs, ease of use, trust, utility and other.

Public online services are perceived as e-Services that can save time, be accessed from anywhere and at any time, help save money and ensure free access to information. According to polls, most important advantages / benefits that electronic services provide are as follows (Figure 6):

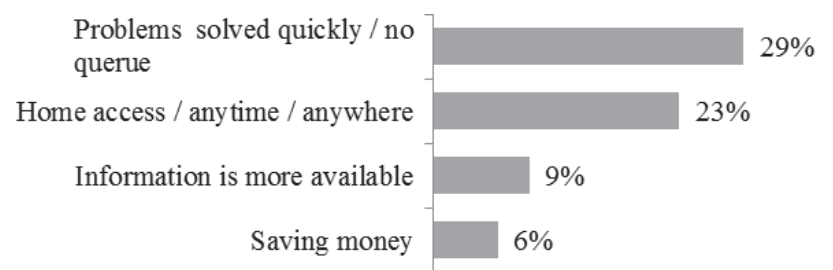

Figure 6: The main advantages / benefits of e-Government, $\%$ of respondents

There are multiple benefits of e-Government services in Moldova. Firstly, they assigned to another level of service culture that are based on social equity, attitude towards citizen, service quality, including availability - anytime, anywhere. Studies on the e-Government implementation [6], [7], [9], [11] showed that acceptance of electronic services by people, especially in developing countries, depends on the ability to overcome certain obstacles: cultural, religious, gender, etc. Such impediments exist in Moldova too [1], [8], especially among older people or those with a lower education level. However, statistics regarding the use of electronic services show that a significant part of the population has adapted quickly enough to the new public services and is aware of their usefulness and expediency.

At the initial stage of implementing the e-Government services we still cannot talk about significant financial benefits [7]. It requires more time for citizens to adapt to the new public services, and also to recover the investment made in e-Government services. According to our estimations, the implementation of criminal record service, for example, has generated benefits amounting to about 32 million MDL during the period under review. The calculations were made on values of time below the average that citizen uses to obtain this service traditionally, reported to the contribution to GDP [7], and transportation costs for obtaining such service. This amount exceeds the total investment chapter Shared Infrastructure and e-Services Development in e-Transformation program governance, carried out during the implementation of this service - about 26 million MDL [4]. 


\section{Local e-Government between wishes and possibilities}

Local authorities, mainly in the rural areas, face difficulties in the implementation of the eGovernment. 57 percent of people live in rural areas in Moldova, according to statistics. Yet, the local administrative units mostly lack capacities of implementing independently high-performance electronic services [1]. Local officials are willing to implement electronic services, but they do not have the means needed to carry out such projects.

Nevertheless, residents of rural areas have a great potential to uptake electronic services. Thus, in $2016,59 \%$ of rural people used Internet compared to $79 \%$ in urban areas and $92 \%$ in Chisinau [8]. $32 \%$ of the rural population accessed websites of government institutions compared to $39 \%$ in urban areas $66 \%$ in Chisinau.

It is worth mentioning that individuals and businesses interact most often with the government at the local level. Therefore, finding solutions for e-government at the local level is an issue of utmost importance.

Most frequently people from rural areas ask for the issuance of:

- $\quad$ Certificates on family composition,

- Certificates from work,

- Certificates on lack of debts to the local budget,

- $\quad$ Certificates on farmland property or lack of it,

- $\quad$ Notary Certificates,

- $\quad$ Certificates for pernancy of assets, property titles.

One of the main reasons that disturb most citizens when interacting with the local government bodies is the lack of access to different channels, long queues, and work schedule of the local authorities. Citizens find it difficult to adjust to the fact that there is a timetable for issuing certificates.

Providing more complex services that require information and approvals from various government agencies takes more time, such as, for example, issuing the permission for clearing green areas of local interest or permission of compliance of construction / maintenance of roads and local public roads.

In our view, to foster the implementation of e-governance at local level, it will be rationally to adopt a generic solution that can be used by a greater number of local authorities, such as the Local Documents Registry. 
The actelocale.md portal offers:

- $\quad$ A registry of all local authorities regardless of their level,

- Modular solution that adjusts to the requirements of any Local Public Administration (LPA),

- Web pages for each participant of the Registry,

- $\quad$ Structured information in accordance with the activities of all LPA,

- Instant access to information,

- Collaboration and practice exchange between different geographic LPA areas,

- $\quad$ Central data base for all documents issued by LPA in Moldova.

\section{Challenges and opportunities}

Electronic public services have become a strong presence in the lives of citizens, in social work and business. The level of support and confidence in the quality and safety of online public services and willingness to recommend them is increasing from year to year. The survey [1] shows that $70 \%$ of people want to use public services online via computer and $63 \%$ via mobile phones. Young and middle-aged employed people, having a better education and an income above the national average, are most receptive to new technologies in public services.

However, there are some signs indicating that a more complex approach is needed for proper development of the e-Government. For example, over the past 3 years, people's confidence that quality of e-Government services will meet their expectations has not increased (Figure 7).

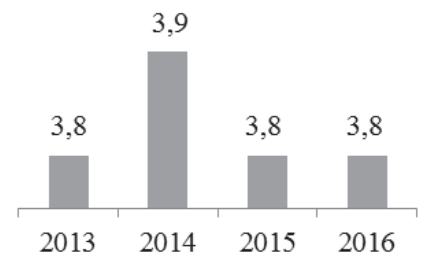

Figure 7: Reliability that e-Government services quality will meet expectations [7]

Also, the number of citizens believing that the e-Government creates benefits also remained unchanged in $2014-2016$ (Figure 8).

There are several explanations for this situation. One of them is that the level of people's expectation as regards the benefits of the e-Government services increases as the phenomenon of eGovernance is better understood. The government should adopt and implement more aggressive policies to implement and promote the e-Government model. 


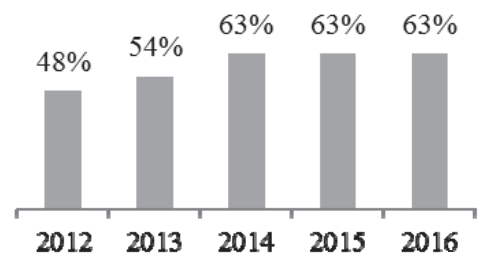

Figure 8: People's opinion on advantages / benefits of e-governance

On the other hand, the content of electronic services and their delivery in Moldova indicates that, at the moment, they are mainly departmental services with a low level of interoperability. Mostly, these are service requests for services.

The changes made so far referred mainly to technical aspects related to requesting or providing online services. The implementation of electronic services has not yet generated crucial structural change of the governance, often pertaining to the specific agency, ministry or public administration which is responsible for these services.

For example, you can apply online to obtain a criminal record. But you will need to take this document from the agency that issued it and then submit it to the institution that requested it.

The maturity of service models is still hovering low level. There are a number of interactive services, and some transactional services initiatives. The service integration phase will be achieved with the implementation of advanced models for interoperability. These activities are provided for in a number of strategic documents in the field - the National Strategy "Moldova Digitala 2020", Strategic Program of technological modernization of governance (e-Transformation) etc.

Implementing e-Government has both a social and an economic impact [7], [5]. E-Government acts as an innovation catalyst on the economic environment. Besides improving labor productivity in the public sector [3], e-Government represents a great opportunity for companies that develop solutions for public services. A priority in this regard is more active involvement of local companies in implementing e-Government solutions.

\section{Conclusion and recommendations}

E-government has become an active presence in Moldova. It did significantly increase citizens' interest in the quality of services, in the government in general. Implementation of e-Government service models generates a comprehensive process of creating new values in public administration. The e-Government affects equally the perception of public authorities about the role of public institutions regarding the interest of citizens and also the citizens' perception on government.

The effects of e-Government are both social and economic. A significant part of citizens understands and accepts e-government services. The number of these citizens is growing. It means that the new approaches to public services are opportune and necessary. Governance is becoming more efficient and more transparent and, with it, citizens' confidence in the government increases.

There are sufficient prerequisites in public administration for a deeper and multilateral development of electronic services. It requires a systemic approach to e-Government services. Electronic services in the public sector have not yet reached a satisfactory level of integration responding to the needs 
of citizens to benefit from complex services in a consistent, across the public sector without the citizen having to know the whole complexity of the structure of government, either central government or local administration.

There are significant differences between the possibilities of implementing electronic services in urban and rural areas. Also, different social groups have a different attitude in terms of awareness and acceptance of e-Government. These challenges require an inclusive approach that would take into account the interests of all these categories of citizens and their ability to integrate in the community of e-Government users.

The government should adopt and implement more aggressive policies to ensure the development and promotion of e-Governance. National ICT infrastructure allows such approach. There are sufficient premises in terms of readiness of an important part of society to accept new service models. The government should be aware that technological changes need to make reforms that aim governance structure and functions.

A special role in implementing of e-Government models can and must play local companies. They could provide expertise, management and new solutions for the public sector both technologically and in terms of complexity and depth of services.

The imperative for new approaches to e-Government services should be interoperability. Interoperability mechanisms and models should be implemented to re-define and re-configure the business process to ensure service delivery and to enhance the efficiency of e-Governance. They will have the ability to enhance the informational coherence of the various agencies and departments of government, the level of integration and maturity of public services in eGovernment system.

\section{References}

[1] Administrative public services provided at local level: diagnosis and opportunities for eTransformation (rom.). Center for Sociological Investigations and Marketing „CBS-AXA”, Urban Development Institute. Chișinău, 2014.

[2] Benchmarking E-government: A Global Perspective. Assessing the Progress of the UN Member States. United Nations - DPEPA, 2002, http://unpan3.un.org/egovkb/Portals/egovkb/ Documents/un/English.pdf

[3] EG4M eGovernment for Mediterranean Countries. Fondo per gli Investimenti della Ricerca di Base (FIRB). Evaluating the Socio-Economic Impact of e-Government. http://siti-server01. siti.disco.unimib.it/eg4m/Doc.pubblici/Deliverable\%20II\%20anno/5.2.2\%20-\%20Evaluating $\% 20$ the $\% 20$ Socio-Economic $\% 20$ Impact $\% 20$ of $\% 20$ e-Government.pdf

[4] Governance eTransformation Project - Financial Statements, 2012, http://egov.md/ro/ transparency/reports/audit-proiect-etransformarea-guvernarii-anul-2012

[5] GRECU, M.: Economic and social impact of eGovernment.. In: Scientific Symposium of Young Researchers. Academy of Economic Studies. Chișinău. (XIII Edition), 24 - 25 April, 2015, pp. 296-301. 
[6] KUMAR, V., MUKERJI, B., BUTT, I. and PERSAUD, A.: Factors for Successful eGovernment Adoption: a Conceptual Framework, The Electronic Journal of e-Government Volume 5 Issue 1, 2007, pp 63 - 76, www.ejeg.com/issue/download.html?idArticle=89

[7] MADRID, L.: The Economic Impact of Interoperability. Connected Government. Microsoft, 2012, http://download.microsoft.com/download/d/0/1/d01533ed-5be2-468b-afac-558ec 549064e/The_Economic_Impact_of_Interoperability.pdf

[8] National survey, Perception, assimilation and acceptance by the population of e-government transformation in Moldova, 2016, http://egov.md/ro/file/3974/download?token=Lnp7lMol

[9] HEEKS, R.: Understanding and Measuring eGovernment: International Benchmarking Studies, 2006, https://pdfs.semanticscholar.org/e23f/0ff178555f885b9a91748a906394c 977 dc5c.pdf

[10] NAMROUSH, S.A.: Citizen Adoption E-government Services Conceptual Framework. http://comp.utm.my/publications/files/2013/04/Citizen-Adoption-E-government-ServicesConceptual-Framework.pdf

[11] AlAwadhi, S. and Morris, A.: Factors Influencing the Adoption of E-government Services. Journal of Software, vol. 4, no. 6, August, 2009, http://www.jsoftware.us/vol4/jsw040613.pdf

[12] KALVET, T., TIITS, M., HINSBERG, H. (editors): Impact assessment of the Estonian egovernment services. Tallinn: Institute of Baltic Studies \& Praxis Center for Policy Studies, 2013, https://www.ibs.ee/wp-content/uploads/Impact_assessment_of_the_Estonian_egovernment_services.pdf

[13] The strategic program of technological modernization of government - e-Transformation. 2011, Monitorul Oficial, Vols. 156-159. http://lex.justice.md/viewdoc.php?action=view\& view $=$ doc\&id $=340301$

[14] United Nations e-Government Survey 2014, E-Government for the future we want, http://unpan3.un.org/egovkb/Portals/egovkb/Documents/un/2014-Survey/E-Gov_Complete _Survey-2014.pdf

[15] United Nations e-Government Survey, 2016, E-Government in Support of Sustainable Development. http://workspace.unpan.org/sites/Internet/Documents/UNPAN96407.pdf 